\title{
Rediscovering a forgotten scientific collection in the Rio Grande do Norte State, Brazil: The herpetological collection of the zoologist José Santiago Lima-Verde
}

\author{
Alcéster Diego Coelho-Lima ${ }^{1,2 *}{ }^{\circledR}$, Marcelo Almeida De Sousa Jucál,3, Ellen Beatriz Fontes da Fonseca ${ }^{4}$, \\ Leticia Cely Vieira de Medeiros ${ }^{3}$ Pamella Barbara Coutinho Soares ${ }^{1,2,4}$, Paulo Victor Araujo Cunha ${ }^{4}$, \\ Daniel Cunha Passos ${ }^{1,2}$ [D \\ ${ }^{1}$ Universidade Federal Rural do Semi-Árido, Centro de Ciências Biológicas e da Saúde, Laboratório de \\ Ecologia e Comportamento Animal, CEP 596259-900, Mossoró, RN, Brasil \\ ${ }^{2}$ Universidade Federal Rural do Semi-Árido, Centro de Ciências Biológicas e da Saúde, \\ Programa de Pós-Graduação em Ecologia e Conservação, CEP 596259-900, Mossoró, RN, Brasil \\ ${ }^{3}$ Universidade Federal Rural do Semi-Árido, Centro de Ciências Agrárias, \\ CEP 596259-900, Mossoró, RN, Brasil \\ ${ }^{4}$ Universidade Federal Rural do Semi-Árido, Centro de Ciências Biológicas e da Saúde, CEP 596259-900, \\ Mossoró, RN, Brasil \\ *Corresponding author: Alcéster Diego Coelho-Lima, e-mail: alcester.coelho@ufersa.edu.br
}

COELHO-LIMA, A.D., SOUSA, M.A., FONSECA, E.B.F., MEDEIROS, L.C.V, SOARES, P.B.C., CUNHA, P.V.A., PASSOS, D.C. Rediscovering a forgotten scientific collection in the Rio Grande do Norte State, Brazil: The herpetological collection of the zoologist José Santiago Lima-Verde. Biota Neotropica. 20(1): e20180706. http://dx.doi.org/10.1590/1676-0611-BN-2018-0706

\begin{abstract}
The zoologist Dr. José Santiago Lima-Verde (1945-2019) made a number of major contributions to the field of animal biology in the northeastern Brazil, in particular through his research with snakes. While employed as a professor at Escola Superior de Agricultura de Mossoró, currently the Universidade Federal Rural do Semi-Árido, Prof. Lima-Verde established a herpetological collection which remained forgotten for a number of decades. In the present study, we describe the revitalization of this collection, which included the updating of the identification of the species and the compilation of the metadata on the collection, which is now named the Coleção Herpetológica Lima-Verde. We catalogued 80 specimens representing 30 species, including 23 species of snakes, five lizards, and two amphisbaenians. One third (30\%) of the specimens had information on dates and sites, with the majority of these specimens being collected in the Brazilian State of Rio Grande do Norte during the 1970's. We also catalogued 315 eggs of seven snake species, from 22 clutches laid in captivity. The collection presents unpublished data and will constitute a reference for future herpetological research on the species found in western region of State of Rio Grande do Norte. Our findings reinforce the importance of zoological collections for the understanding of patterns of biodiversity, and we would recommend the creation of more regional scientific collections and the broader recognition of their value as a basic source of biological data.
\end{abstract}

Keywords: Biodiversity, Caatinga, Northeastern Brazil, Scientific Collections, Semiarid.

\section{Redescobrindo uma coleção científica esquecida no Estado do Rio Grande do Norte, Brasil: A coleção herpetológica do zoólogo José Santiago Lima-Verde}

Resumo: O zoólogo Dr. José Santiago Lima-Verde (1945-2019) fez uma série de importantes contribuições para o campo da biologia animal no nordeste do Brasil, em particular através de sua pesquisa com serpentes. Enquanto professor da Escola Superior de Agricultura de Mossoró, atualmente Universidade Federal Rural do Semi-Árido, o Prof. Lima-Verde estabeleceu uma coleção herpetológica que permaneceu esquecida por várias décadas. No presente estudo, descrevemos a revitalização dessa coleção, que incluiu a atualização da identificação das espécies e a compilação dos metadados da coleção, que agora é denominada Coleção Herpetológica Lima-Verde. Nós catalogamos 80 espécimes representando 30 espécies, incluindo 23 espécies de serpentes, cinco lagartos e duas anfisbenas. Um terço (30\%) dos exemplares possuíam informações sobre datas e locais de coleta, sendo a maioria desses espécimes coletados no Estado do Rio Grande do Norte durante a década de 1970. Também catalogamos 315 ovos de sete espécies de serpentes, provenientes de 22 ninhadas obtidas em cativeiro. A coleção apresenta dados inéditos e constituirá uma referência para futuras pesquisas herpetológicas sobre as espécies encontradas na região oeste do Estado do Rio Grande do Norte. Nossos achados reforçam a importância das coleções zoológicas para a compreensão dos padrões de biodiversidade, e nós recomendamos a criação de mais coleções científicas regionais e o reconhecimento mais amplo de seu valor como fonte básica de dados biológicos.

Palavras-chave: Biodiversidade, Caatinga, Nordeste do Brasil, Coleções Cientificas, Semiárido. 


\section{Introduction}

Zoological collections provide a wealth of information on wild animals, ranging from specimens (complete or partial) to samples of tissues, photographs, and recordings of vocalizations (Franco 2002, Vivo et al. 2014). These collections support the continuous and systematic accumulation of biological data, which provide important insights into the present and past configuration of a region's fauna (Marinoni \& Peixoto 2010, Zaher \& Young 2003). Given their historical context and wealth of information, zoological collections constitute one of the principal sources of data for a range of research fields, including taxonomy, ecology, and biogeography.

The zoologist Dr. José Santiago Lima-Verde (1945-2019) was one of the principal scientists responsible for the late advances in herpetological research in the Northeast region of Brazil in the second half of the 20th Century (Fernandes-Ferreira et al. 2014). His legacy includes the first records of a number of Amazonian reptiles in the semi-arid Caatinga domain, such as the Imantodes cenchoa (Linnaeus, 1758) and Mastigodryas boddaerti (Sentzen, 1796) (Nascimento \& Lima-Verde, 1989), as well as descriptions of new species, including the lizard, Colobosauroides cearensis Cunha, Lima-Verde \& Lima, 1991, and the caecilian, Chthonerpeton arii Cascon \& Lima-Verde, 1994. Some of Dr. Lima-Verde's most important contributions on the reptilian fauna of the Caatinga of Rio Grande do Norte were the study "Fisioecologia e etologia de algumas serpentes da Chapada do Apodi" (Lima-Verde 1976), in which he described the ecology and behavior of 20 species, and the description of the snake Erythrolamprus mossoroensis (Hoge \& Lima-Verde, 1972), whose type-locality is the municipality of Mossoró (Hoge \& Lima-Verde 1972).

As a professor at Escola Superior de Agricultura de Mossoró (ESAM), currently the Universidade Federal Rural do Semi-Árido (UFERSA), Dr. Lima-Verde collected a number of reptile specimens during his research activities, creating a personal herpetological collection. Years later, after being transferred to the Universidade Federal do Ceará (UFC), Dr. Lima-Verde founded this institution's herpetological collection using specimens from his personal collection (Fernandes-Ferreira et al. 2014). However, part of this personal collection remained at the ESAM, where it was, forgotten, for a number of decades. Given the importance of zoological collections for the understanding of patterns of biodiversity, and the scientific legacy of Dr. Lima-Verde, in the present study, we $i$. revitalized the remaining material of his particular collection; $i$. updated the identification of the specimens, and iii. made the collection available for future herpetological research.

\section{Material and Methods}

\section{Revitalization of the collection}

We retrieved the specimens collected by Dr. Lima-Verde, which had been left in the annex of the Laboratório Didático de Zoologia from the UFERSA, and transferred them to the Laboratório de Ecologia e Comportamento Animal (LECA). The material was poorly preserved, with many containers being damaged or inadequately sealed. Some specimens were exposed (not immersed properly), while others were in alcohol at concentrations of below $70 \%$. We replaced the containers of the specimens that could be recuperated, and renewed the preserving fluid. We discarded the specimens that had decomposed due to inadequate storage conditions, and obtained a photographic record of all the revitalized specimens.

\section{Taxonomic update}

We identified all the specimens recovered from the Laboratório Didático de Zoologia to the lowest possible taxonomic level, using sources on the target taxa (Peters \& Orejas-Miranda 1970, Campbell \& Lamar 2004, Passos \& Fernandes 2008, Pyron et al. 2013, Bernarde 2014). We made an individually-numbered plastic label for each of the specimens recuperated, but we also took care to maintain the original, handwritten labels still attached to the specimens. We deposited all the material that had information on the collecting locality and date in the scientific collection Coleção Herpetológica do Semiárido (CHSA).

\section{Results}

We recuperated 80 specimens and 315 eggs (Figure 1). This set of biological specimens now constitutes the Coleção Herpetológica Lima-Verde - CHLV. The specimens we recuperated belong to 30 species, including 23 snakes $(\mathrm{N}=56$ specimens), five lizards $(\mathrm{N}=$ $21)$, and two amphisbaenians $(\mathrm{N}=3)$. Erythrolamprus poecilogyrus $(\mathrm{N}=11$ specimens), Ameivula ocellifera $(\mathrm{N}=9)$, and Amphisbaena vermicularis $(\mathrm{N}=2)$ were the most abundant species of snakes, lizards, and amphisbaenians, respectively (Table 1).

Overall, 19 (24\%) of the 80 specimens we recuperated were labeled with information on the locality and $24(30 \%)$ with the collection date. These specimens were collected between 1970 and 1994 (Figure 2), although the majority ( $58 \% ; \mathrm{N}=14)$ were obtained in the 1970 's. The vast majority $(74 \% ; \mathrm{N}=14)$ of the specimens from known localities were collected in the municipality of Mossoro (Figure 3). With the exception of the four Bothrops species (17\% of the total), all the taxa occur in the Caatinga biome.

The 315 snake eggs we recuperated during the study were derived from clutches obtained in captivity between June and November, 1971 (Figure 1a). Based on the labels, 275 of these eggs were produced by seven different snake species (Table 2), although 40 eggs from six clutches were unlabeled. While Lygophis dilepis had the largest number of eggs $(\mathrm{N}=150)$, Philodryas nattereri was represented by the largest number of clutches $(\mathrm{N}=7)$.

\section{Discussion}

The specimens deposited in the Coleção Herpetológica Lima-Verde were collected predominantly in the Rio Grande do Norte. This is related to the fact that Dr. José Santiago Lima-Verde conducted extensive research in the region of the Apodi Plateau, which lies on the border between the states of Ceará and Rio Grande do Norte (Lima-Verde 1976, Fernandes-Ferreira et al. 2014). Most of the species in the collection present wide geographic distribution, and are found in more than one South American morphoclimatic domain, including the Caatinga (Cavalcanti et al. 2014, Caldas et al. 2016). The exceptions are Epicrates assisi, Epictia borapeliotes, and Erythrolamprus mossoroensis which are endemic to the Caatinga (Hoge \& Lima-Verde 1972, Guedes et al. 2014), and the four pitvipers (Bothrops brazili, B. jararacussu, B. fonsecai, and B. neuwiedi), which may have been acquired by Dr. 


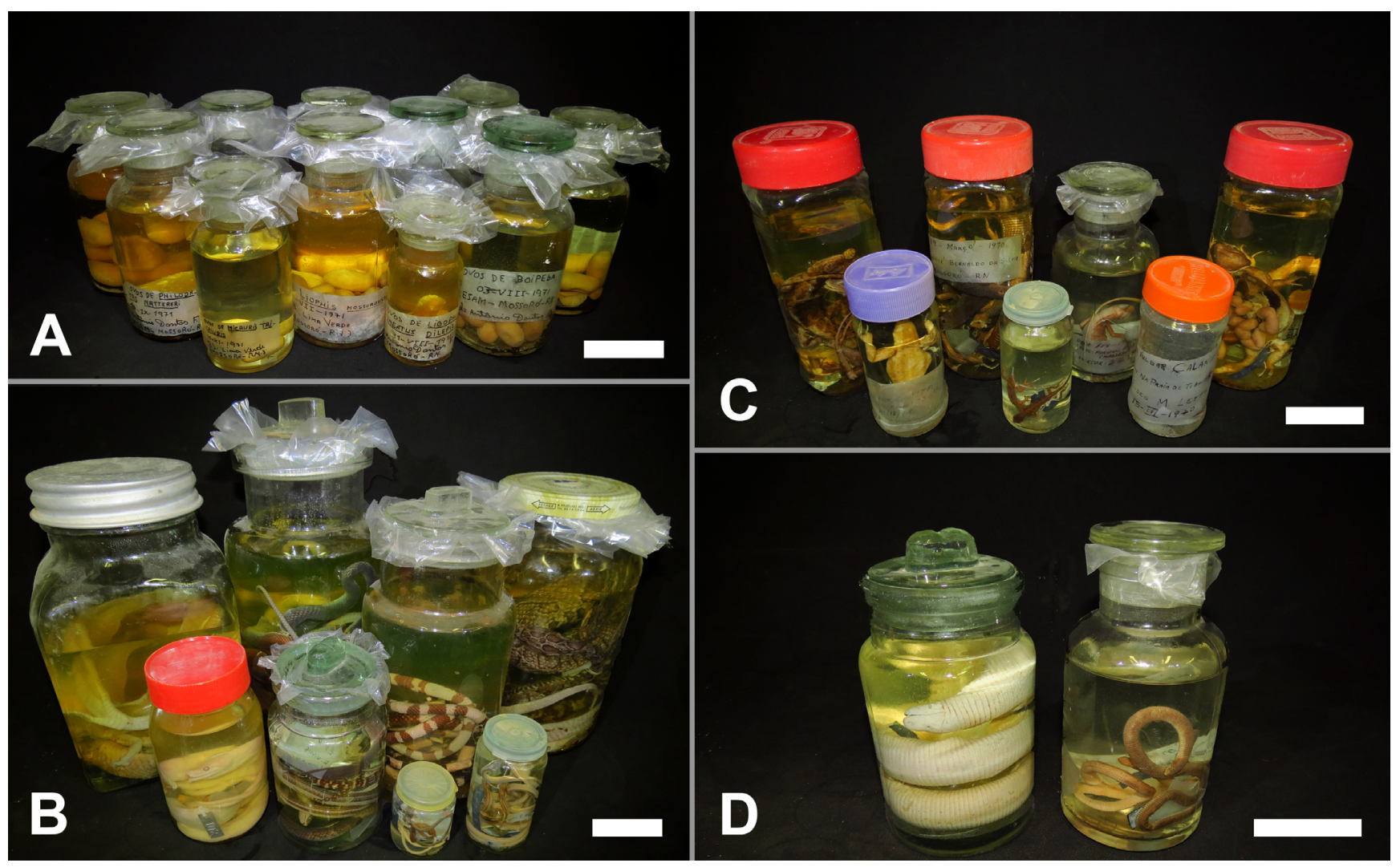

Figure 1. Sample of eggs (A), snakes (B), lizards (C), and amphisbaenians (D) of the Coleção Herpetológica Lima-Verde (CHLV). Scale bars $=5 \mathrm{~cm}$.

Lima-Verde through scientific partnerships with the Instituto Butantan in São Paulo (e.g. Hoge \& Lima-Verde 1972) and the Museu Paraense Emílio Goeldi in Belém (e.g. Cunha et al. 1991).

Most (70\%) of the specimens deposited in the Coleção Herpetológica Lima-Verde are snakes, reflecting the research interests of Dr. LimaVerde (Hoge \& Lima-Verde 1972, Lima-Verde 1976, Nascimento \& Lima-Verde 1989). The most numerous species in the collection (Erythrolamprus poecilogyrus and Ameivula ocellifera) are known to be common in the Depressão Sertaneja Setentrional ecoregion (Mesquita et al. 2013, Passos et al. 2016). Three specimens (two snakes and one lizard) could not be identified due to their advanced decomposition, and a further three snake specimens could only be identified to genus. Despite this lack of identification, we can speculate on the taxonomic status of these last three specimens. The Thamnodynastes specimen was identified by Lima-Verde (1976) as Thamnodynastes nattereri, although, in fact, it seems likely be the recently described Thamnodynastes phoenix Franco, Trevine, Montingelli \& Zaher, 2017, whose name refers to the fact that the type series was rescued from the fire that destroyed the herpetological collection of the Instituto Butantan in 2010 (Franco et al. 2017). The Micrurus specimen may represent a species from the Caatinga domain that has yet to be described formally, but is normally identified as Micrurus ibiboboca (Merrem, 1820) (Argôlo 2004, Guedes et al. 2014). The Xenodon specimen, which was dissected and is badly damaged, appears to be Xenodon merremii (Wagler in Spix, 1824), the only species of this genus found in the northern portion of the Caatinga domain (Costa \& Bérnils 2018).
During the time he spent in Mossoró, Dr. Lima-Verde conducted a number of behavioral studies of captive snakes. These snakes were cared for by the ESAM's laboratory assistant, Mr. Antônio Dantas Feitoza, who stored the clutches produced by the snakes in separate containers labeled with information on the species, origin, and date of oviposition. This systematic record contributed to the recuperation of the 315 snake eggs listed here (Table 2), which constituted probably part of the reproductive data presented by Lima-Verde (1976) in his study on the snakes of the Apodi Plateau. Despite this, no data have ever been published on the size of the eggs or clutches in these species. In this context, the data on Lygophis dilepis and Philodryas nattereri are especially interesting, given that the reproductive parameters of these species are known only from a few Caatinga populations (Vitt 1980, 1983, Mesquita et al. 2011, Passos et al., 2014). The two clutches recorded here for Erythrolamprus mossoroensis are also extremely important, given that the biology of this Caatinga endemic species is still virtually unknown. We have now made these data available for future research on the snake species of the Caatinga region.

The rediscovery of the Coleção Herpetológica Lima-Verde has not only permitted the recuperation of one of Dr. Lima-Verde's most important contributions to the zoology of northeastern Brazil, but also represents a valuable scientific legacy, which provides important insights into research conducted almost half a century ago. The revitalization of this collection has also expanded our historical knowledge on the herpetofauna of the semi-arid region of Rio Grande do Norte, given that the collection provides novel data on the biology of a number of 
Table 1. Number of specimens recuperated of each reptile species deposited in the Coleção Herpetológica Lima-Verde (CHLV). The species are ranked by the number of specimens, in decreasing order. The specimens for which information on the collecting locality and date is available were deposited in the Coleção Herpetológica do Semiárido (CHSA), with the respective catalogue number being shown within parentheses.

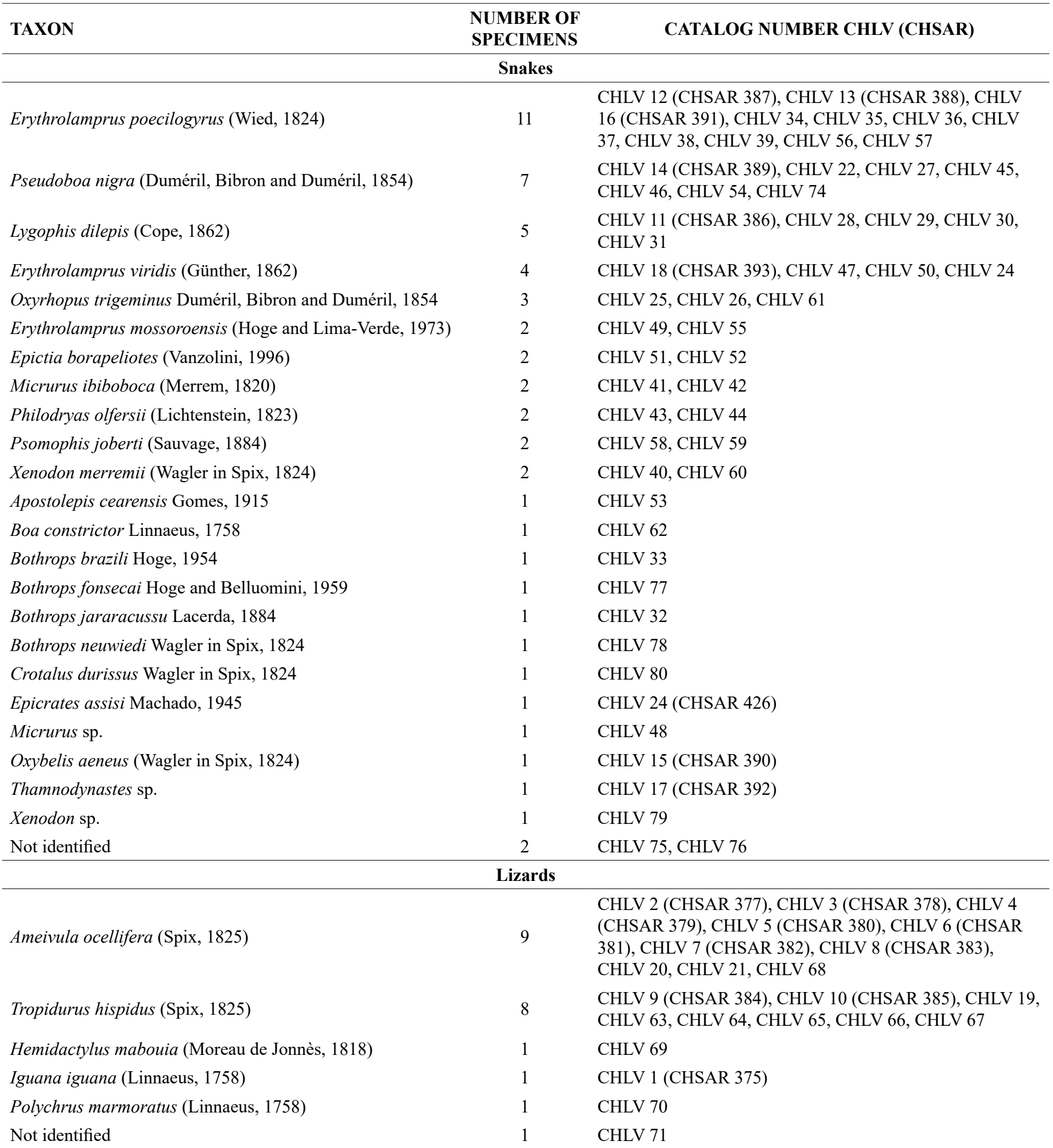




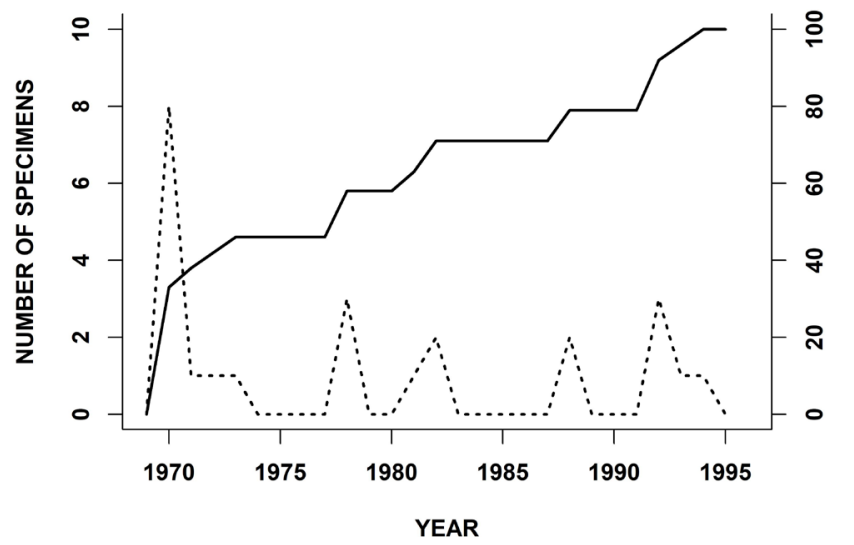

Figure 2. Number of the dated specimens $(\mathrm{N}=24)$ collected per year (dotted line) and the cumulative percentage of dated specimens in the Coleção Herpetológica Lima-Verde between 1970 and 1994.

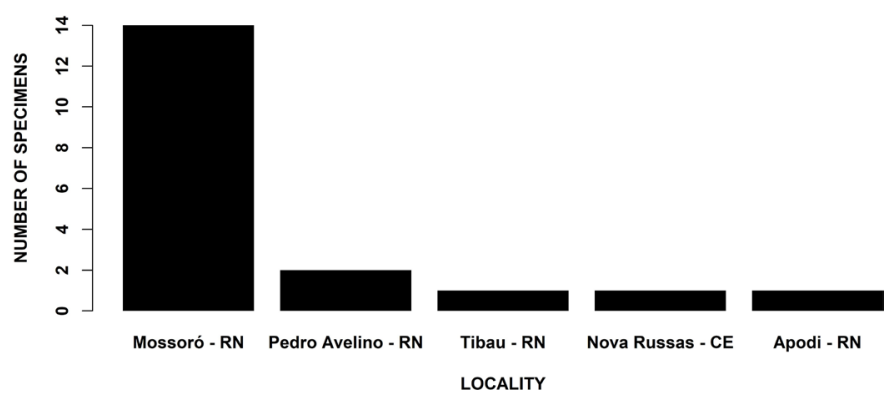

Figure 3. Collecting localities (municipality - state; $\mathrm{CE}=$ Ceará, $\mathrm{RN}=$ Rio Grande do Norte) of the 19 labeled specimens in the Coleção Herpetológica Lima-Verde, collected between 1970 and 1994.

Table 2. The number of eggs and clutches per snake species recuperated during the present study, now part of the Coleção Herpetológica Lima-Verde (CHLV). The material was collected between June and November, 1971. The species are ranked by the number of eggs, in decreasing order.

\begin{tabular}{lcc}
\hline Species & Clutches & Eggs \\
\hline Lygophis dilepis (Cope, 1862) & 6 & 150 \\
Philodryas nattereri Steindachner, 1870 & 7 & 56 \\
Erythrolamprus mossoroensis (Hoge \& & 2 & 33 \\
Lima-Verde, 1973) & 4 & 15 \\
Erythrolamprus viridis (Günther, 1862) & 4 & 12 \\
Xenodon merremii (Wagler in Spix, 1824) & 1 & 5 \\
Micrurus sp. & 1 & 4 \\
Pseudoboa nigra (Duméril, Bibron \& & 1 & 4 \\
Duméril, 1854) & & 40 \\
Not identified & 6 & 4 \\
\hline
\end{tabular}

very poorly-known species. Our findings also highlight the importance of regional scientific collections, which may provide valuable insights into the diversity of local faunas, as well as helping to offset the loss of material caused by recent incidents in major collections. The recent losses of collections in the fires at the Instituto Butantan in 2010, and at the Museu Nacional in 2018, were both the result of reduced investment in infrastructure and maintenance. In this context, we would emphasize the need for official incentives for the curatorship and maintenance of scientific collections throughout Brazil, but especially in poorly-studied regions, like the Caatinga, which are highly underrepresented. Long-term support for these collections will be essential to guarantee the understanding of the country's biodiversity by future generations.

\section{Aknowledgments}

We are extremely grateful to Dr. José Santiago Lima-Verde's wife, Mrs. Ana Célia França Santiago, for providing essential information and authorizing the publication of these data. At the time of submission, Mrs. Lima-Verde informed us of the poor health of Dr. Lima-Verde, which prevented him from participating directly in the present study. Unfortunately the Dr. Lima-Verde passed away during the review process of this paper. Therefore, we dedicated this publication in memoriam of Dr. José Santiago Lima-Verde. We would also like to thank Mr. João Batista Bispo Soares Junior, technician at the Laboratório Didático de Zoologia from UFERSA, for helping to recover the zoological specimens, and for helping us to contact $\mathrm{Mr}$. Antônio Dantas Feitoza, ex-ESAM employee and laboratory assistant of Dr. Lima-Verde. ACL wishes to thank the Fundação de Apoio à Pesquisa do Rio Grande do Norte (FAPERN) and the Coordenação de Aperfeiçoamento de Pessoal de Nível Superior (CAPES - Finance Code 001), for providing a graduate (masters) scholarship. ACL would also like to thank class 2017.2 of the Comunicação Científica course of the Programa de Pós-Graduação em Ecologia e Conservação (PPGEC) for their contributions on an early draft of this manuscript. DCP thanks the PPGEC coordination for financial support for the language revision and publication of this manuscript.

\section{Author Contributions}

Alcéster Diego Coelho-Lima: Contribution to data collection, contribution to data analysis and interpretation, contribution to manuscript preparation, contribution to critical revision, adding intelectual content.

Marcelo Almeida de Sousa Jucá: Contribution to data collection, contribution to data analysis and interpretation.

Ellen Beatriz Fontes da Fonseca: Contribution to data collection, contribution to data analysis and interpretation.

Leticia Cely Vieira de Medeiros: Contribution to data collection.

Pamella Barbara Coutinho Soares: Contribution to data collection, contribution to data analysis and interpretation.

Paulo Victor Araujo Cunha: Contribution to data collection.

Daniel Cunha Passos: Substantial contribution in the concept and design of the study, contribution to data collection, contribution to data analysis and interpretation, contribution to manuscript preparation, contribution to critical revision, adding intelectual content.

\section{Conflicts of interest}

The authors declare that they have no conflict of interest related to the publication of this manuscript. 


\section{References}

ARGÔLO, A. J. S. 2004. As serpentes dos cacauais do sudeste da Bahia. Editus.

BERNARDE, P. S. 2014. Serpentes peçonhentas e acidentes ofídicos no Brasil. São Paulo: Anolisbooks.

CALDAS, F. L. S., COSTA, T. B., LARANJEIRAS, D. O., MESQUITA, D. O., \& GARDA, A. A. 2016. Herpetofauna of protected areas in the Caatinga V: Seridó Ecological Station (Rio Grande do Norte, Brazil). Check List 12(4).

CAMPBELL, J. A., \& LAMAR, W. W. 2004. The venomous reptiles of the Western Hemisphere, vol. I. Comstock Publishing Associates, Ithaca.

CAVALCANTI, L. B. DE Q., COSTA, T. B., COLLI, G. R., COSTA, G. C., FRANÇA, F. G. R., MESQUITA, D. O., PALMEIRA, C. N. S., PELEGRIN, N., SOARES, A. H. B., TUCKER, D. B., \& GARDA, A. A. 2014. Herpetofauna of protected areas in the Caatinga II: Serra da Capivara National Park, Piauí, Brazil. Check List 10(1), 18-27.

COSTA, C., \& BÉRNILS, R. S. 2018. Répteis do Brasil e suas Unidades Federativas: lista de espécies. Herpetologia Brasileira 8, 11-57.

CUNHA, O. R., LIMA-VERDE, J. S., \& LIMA, A. C. M. 1991. Novo gênero e espécie de lagarto do Estado do Ceará (Lacertilia: Teiidae). Boletim do Museu Paraense Emilio Goeldi, Série Zoologia 7(2), 163-176.

FERNANDES-FERREIRA, H., NASCIMENTO, H., LIMA, D. C., GURGELFILHO, M., \& ALVES, R. R. N. 2014. História da zoologia no Estado do Ceará Parte I: vertebrados continentais. Gaia Scientia 8(1), 99-120.

FRANCO, F. L., TREVINE, V. C., MONTINGELLI, G. G., \& ZAHER, H. 2017. A new species of Thamnodynastes from the open areas of central and northeastern Brazil (Serpentes: Dipsadidae: Tachymenini). Salamandra 53(3), 339-350.

FRANCO, F. L. 2002. Coleções zoológicas. In P. Auricchio \& M. G. Salomão (Eds.), Técnicas de coleta e preparação de vertebrados para fins científicos e didáticos (pp. 281-318). Terra Brasilis Editora Ltda.

GUEDES, T. B., NOGUEIRA, C., \& MARQUES, O. A. V. 2014. Diversity, natural history, and geographic distribution of snakes in the Caatinga, Northeastern Brazil. Zootaxa (Vol. 3863).

HOGE, A. R., \& LIMA-VERDE, J. S. 1972. Liophis mossoroensis nov. sp. do Brasil [Serpentes: Colubridae]. Memórias do Instituto Butantan 36, 215-220.

LIMA-VERDE, J. S. 1976. Fisioecologia e etologia de algumas serpentes da Chapada do Apodi, Estados do Ceará e Rio Grando do Norte (Brasil). Caatinga 1(1), 21-56.
MARINONI, L., \& PEIXOTO, A. L. 2010. As coleções biológicas como fonte dinâmica e permanente de conhecimento sobre a biodiversidade. Ciência e Cultura 62(3), 54-57.

MESQUiTA, P. C. M. D., PASSOS, D. C., BORGES-NOJOSA, D. M., \& CECHIN, S. Z., 2013. Ecologia e história natural das serpentes de uma área de Caatinga no Nordeste brasileiro. Papéis Avulsos de Zoologia 53, 99-113.

MESQUiTA, P. C. M. D., BORGES-NOJOSA, D. M., PASSOS, D. C., \& BEZERRA, C. H. 2011. Ecology of Philodryas nattereri in the Brazilian semi-arid region. Herpetological Journal 21, 193-198.

NASCIMENTO, F. P., \& LIMA-VERDE, J. S. 1989. Ocorrência de ofídios de ambientes florestais em enclaves de matas úmidas do Ceará (Ophidia: Colubridae). Boletim do Museu Paraense Emilio Goeldi, Série Zoologia 5(1), 95-100.

PASSOS, D. C., MESQUITA, P. C. M. D., \& BORGES-NOJOSA, D. M. 2016. Diversity and seasonal dynamic of a lizard assemblage in a Neotropical semiarid habitat. Studies on Neotropical Fauna and Environment 51(1), 19-28.

PASSOS, D. C., MESQUITA, P. C. M. D., BRANDÃO, A. L. R., BORGESNOJOSA, D. M., 2014. Dissimilar ab ovo: Sexual dimorphism of Philodryas nattereri Steindachner, 1870 hatchlings and juveniles. Herpetozoa 26, 178-180.

PASSOS, P., \& FERNANDES, R. 2008. Revision of the Epicrates cenchria complex (Serpentes: Boidae). Herpetological Monographs 22(22), 1-30.

PETERS, J. A., \& OREJAS-MIRANDA, B. R. 1970. Catalogue of the Neotropical Squamata: Part I. Snakes. National Museum of the United States Bulletin 297, 1-347.

PYRON, R. A., BURBRINK, F. T., \& WIENS, J. J. 2013. A phylogeny and revised classification of Squamata, including 4161 species of lizards and snakes. BMC Evolutionary Biology 13(1), 93.

VIVO, M. DE, SILVEIRA, L. F., \& NASCIMENTO, F. O. 2014. Reflexões sobre coleções zoológicas, sua curadoria e a inserção dos museus na estrutura universitária brasileira. Arquivos de Zoologia 45, 105-113.

VITT, L. J. 1980. Ecological observations on sympatric Philodryas (Colubridae) in Northeastern Brazil. Papéis Avulsos de Zoologia 34(5), 87-98.

VITT, L. J. 1983. Ecology of an anuran-eating guild of terrestrial tropical snakes. Herpetologica 39, 52-66.

ZAHER, H., \& YOUNG, P. S. 2003. As coleções zoológicas brasileiras: panorama e desafios. Ciência e Cultura 55(3), 24-26.

Received: 05/12/2018

Revised: 11/09/2019

Accepted: 16/10/2019

Published online: 25/11/2019 